FAO: Nutrition Committee (1948). F.A.O. Nutr. Mtgs Rep. Ser. no. 2.

FAO/WHO (1954). F.A.O. Nutr. Mtgs Rep. Ser. no. 8.

FAO/WHO: Joint Expert Committee on Nutrition (195I). F.A.O. Nutr. Mtgs Rep. Ser. no. 5. Also published as WHO tech. Rep. Ser. no. 44 .

FAO/WHO: Joint Expert Committee on Nutrition (1953). F.A.O. Nutr. Mtgs Rep. Ser. no. 7. Also published as WHO tech. Rep. Ser. no. 72.

FAO/WHO: Joint Expert Committee on Nutrition (1955). F.A.O. Nutr. Mtgs Rep. Ser. no. 9. Also published as WHO tech. Rep. Ser. no. 97.

FAO/WHO: Nutrition Committee for South and East Asia (1950). F.A.O. Nutr. Mtgs Rep. Ser. no. 3. FAO/WHO: Nutrition Committee for South and East Asia (1953). F.A.O. Nutr. Mtgs Rep. Ser. no. 6.

FAO/WHO/Josiah Macy Jr. Foundation (1955). Protein Malnutrition. Proceedings of a Conference in famaica (1953). [J. C. Waterlow, editor.] Cambridge: University Press.

Ministry of Food: National Food Survey Committee (1952). Domestic Food Consumption and Expenditure, 1950. London: H.M. Stationery Office.

Ministry of Food: National Food Survey Committee (1953). Domestic Food Consumption and Expenditure, I951. London: H.M. Stationery Office.

Norris, T. (1949). F.A.O. nutr. Stud. no. 4 .

Reh, E., Castellanos, A. \& Bravo de Rueda, Y. (1954). Bull. Pan-Amer. sanit. Bur. 1, 32.

Reh, E. \& Fajardo, G. (I955). Condiciones de Vida y de Alimentacion de Algunos Grupos de Poblacion Urbana y Rural de la Zona Central de Honduras. Honduras: Department of Nutrition, Ministry of Health and Welfare.

Reh, E., Fernández, C. \& Méndez, P. (1955). Condiciones de Vida y de Alimentacion en Cuatro Grupos de Poblacion de la Zona Central de Costa Rica. Bull. Pan-Amer. sanit. Bur. (In the Press.)

Ritchie, J. A. S. (1950). F.A.O. nutr. Stud. no. 6.

Ross, A. C. (1956). Proc. Nutr. Soc. 15, 30.

Scott, M. L. (1953). F.A.O. nutr. Stud. no. 10.

Secretariat of The United Nations Children's Fund (UNICEF) (1956). Proc. Nutr. Soc. 15, 22.

Williams, C. D. (1954). Lancet, 266, 323.

\title{
WHO and nutrition
}

By R. C. Burgess, Chief, Nutrition Section, World Health Organization, Palais des Nations, Geneva, Switzerland

The Nutrition Section of WHO is a small unit-part of the Division of Organization of Public Health Services. Until recently it consisted of a Section Chief only, but has now been strengthened by the appointment of a second health officer with experience in nutritional problems. It has, however, the co-operation of the other sections in the Division-particularly those dealing with maternal and child health and health education of the public.

WHO is concerned with all aspects of health, and malnutrition is probably one of the most important causes of ill health throughout the world to-day. In many countries a combination of disease and malnutrition exists and is responsible for high mortality and morbidity rates in the younger age groups. More effective control of the intercurrent infections and infestations has now made it possible to see the full significance of malnutrition as a public-health problem.

No attempt is made in this paper to describe all our activities in the field of nutrition, but a brief account of our approach to some of the more important problems will perhaps show the contribution an international agency can make towards reducing nutritional disease. First I will describe our work on endemic goitre in which, as we all know, our Chairman to-day did such important original research. 


\section{Goitre}

Endemic goitre has widespread effects on the well-being of a community. Cretinism, feeblemindedness, and a lowered educational ability are associated with it. Reports have suggested a significant correlation between the incidence of deafmutism and that of endemic goitre. There is also an increase in the number of thyroid operations performed which represents an additional economic burden, and there is evidence that the incidence of hyperthyroidism and carcinoma of the thyroid is higher where endemic goitre is found.

This, then, is a major public-health problem in many parts of the world, responsible for poor social and economic conditions as well as ill health. McCarrison (I9 I 7) estimated that there were some 5,000,000 persons suffering from goitre in India alone. Ramalingaswami (1953) considers that this estimate would not be far from valid to-day.

The statement of the Medical Research Council: Goitre Subcommittee (I944) that 'the immediate cause of simple goitre is failure of the thyroid gland to obtain a supply of iodine sufficient to maintain its normal structure and function' is generally accepted. And its conclusion 'although goitrogenic factors appear to play an important part in the production of goitre in some areas, there is no reason to doubt that endemic goitre can always be prevented by providing the amount of iodine needed' has been clearly confirmed by the almost total eradication achieved in many western countries.

Prevention in the underdeveloped countries has, however, been beset with technical problems and various measures have been tried, without, on the whole, much success. There appeared to be a need for a study of the whole problem and this was therefore undertaken.

A number of consultants were engaged by WHO to visit countries in Europe, Asia and South America. Information on the use of iodized salt, and, in areas where this measure could not be applied, on other methods of supplying iodine to deficient populations was collected.

Where refined salt is in general use, the addition of potassium iodide to the salt is a satisfactory method of meeting the deficiency of iodine, and has been used in countries in which endemic goitre has been controlled. Refined salt is not, however, in general use in many of the affected countries and other methods such as the addition of iodine to drinking water, or administration in various other forms, such as drops or tablets, have been proposed. These measures are, in most circumstances, either uneconomical or so difficult to organize that they are likely to be ineffectual in practice. Accumulated experience indicated that the best means of prevention is the consumption of a salt that has been artificially iodized. Where refined salt was not widely used, the iodization of crude salt, if this were possible, appeared to be the procedure most likely to meet with success.

The first problem to be solved was the introduction of iodine into the crude salt. The ease and practicability of iodizing salt depends largely on the methods of production of salt and there was no adequate method of iodizing crude salt. The World 
Health Organization therefore requested the Chilean Iodine Educational Bureau of London to study procedures with a view to developing such a method. As a result of this study (Holman, 1953) a simple technique has been developed which has proved entirely successful on a small scale and which can easily be developed to iodize crude salt on a very extensive scale.

The second difficulty that had to be overcome was the instability in crude salt of iodine in the form of iodide. The Chilean Iodine Educational Bureau has carried out numerous tests; Kelly (1953) has summarized all the available work on this particular problem for WHO. The stability of iodine in the form of iodide is determined by a number of factors, and it has been found that iodates have certain advantages over iodides, the principal one being their stability under adverse conditions of moisture, sunlight, heat and impurities in the salt.

In considering the use of iodates for iodizing salt, certain questions arose. The first of these was the danger of toxicity, for early pharmacological studies had suggested that iodates were very much more toxic than iodides.

This aspect of the problem was studied by the Medical Research Council in England (Murray, 1953) and by the Food and Drugs Administration and the United States Public Health Laboratories in the United States (personal communication). Examination of the earlier material showed that iodates had been administered by injection. When given by mouth sodium iodate has proved to have a very low toxicity.

Studies have been carried out in England on the availability of iodine taken by mouth in the form of iodate (Murray \& Pochin, 1951). It appears that almost all of the iodine of the iodate is available to the thyroid gland. Lastly, the effectiveness of iodates in the prevention of goitre has been adequately tried out in well-controlled field experiments in Central America (Scrimshaw, Cabezas, Castillo \& Méndez, 1953). These field trials indicate that they are as effective as iodides.

As a result of these activities ranging from the development of machines for iodizing salt to field experiments in control of endemic goitre, a new and effective method of preventing goitre in the many countries where it occurs, and where refined salt is not in general use, is now available.

It seemed to WHO, however, that it might be well worth while to go a step further and try to assist countries to develop this new technique on a country-wide basis. In 1954 two consultants-a chemical engineer on the staff of the Chilean Iodine Educational Bureau, and a physician from Latin America with extensive experience in the public-health aspects of endemic goitre-visited sixteen countries in Latin America. The recommendations of these consultants were accepted by each country and the majority are now proposing to take action to provide iodized salt for their populations.

Every effort will now be made to collect and correlate information concerning the reduction in goitre incidence achieved by the use of iodized salt, and the results of administering iodized salt at different levels of iodization.

The FAO/WHO: Joint Expert Committee on Nutrition (1955) after reviewing the WHO activities in this field has recommended among other things: 
(1) The publication of a monograph on all the public-health aspects of the subject;

(2) The carrying out of surveys in countries which will determine the incidence of goitre and also provide a basis for evaluation of the preventive measures, including the subsequent economic and social changes.

There is a great deal still to do in the control of endemic goitre, and attention must be concentrated on the continuing importance of the disease as a public-health problem. Nevertheless, with the co-operation of various workers in the United Kingdom, the United States and Latin America it has been possible to develop an effective means of control where none existed.

\section{Kwashiorkor}

Another aspect of our work concerns the most widespread nutritional problem affecting the general standard of public health in the world to-day, namely, the disease commonly known as kwashiorkor. The Joint FAO/WHO Expert Committee on Nutrition in its first session in I949, recommended that WHO should conduct inquiries into the various features of this disease, including the clinical manifestations and associated food habits, particularly during pregnancy, lactation, infancy and early childhood, that these investigations should be carried out in areas where the living conditions of the people appeared to be similar but the incidence of the disease differed greatly, and that attention should be paid to the importance of tropical parasitism as a causative factor (FAO/WHO: Joint Expert Committee on Nutrition, I950).

Three separate surveys in Africa (Brock \& Autret, 1952), Central America (Autret \& Behar, 1954) and Brazil (Waterlow \& Vergara, 1955) have been carried out in association with an FAO staff member. In $195^{2}$ two meetings concerned with this problem took place in Fajara, Gambia, West Africa. The first of these was the InterAfrican Conference on Nutrition held under the auspices of the Commission for Technical Co-operation in Africa, South of the Sahara (CCTA). Professor Platt, Director of the Medical Research Council's Human Nutrition Research Unit, was the moving spirit in the organization of this conference, which was attended by most of the well-known workers in kwashiorkor from the various territories in that continent.

After consultation and planning with CCTA authorities, FAO and WHO decided to convene the third session of their joint Expert Committee on Nutrition in Fajara, immediately after the CCTA conference. Members of this Committee came from Portugal, Belgium, Italy, France, India, the Carribean and the United States as well as from Africa. They attended the Conference and participated in the technical discussions. The bringing together of these two groups of workers from different parts of the world was, I think, valuable. Fajara itself is an excellent place to hold such a meeting. The conditions under which the disease is prone to occur, as well as actual clinical cases, could be seen. A valuable report on this conference (Commission for Technical Co-operation in Africa, South of the Sahara (CCTA), 1954) is now available. 
The Expert Committee meeting benefited greatly from the papers and discussions during the 8 days of the CCTA Conference. The report of the Committee advised our organizations on future policy in relation to this problem and stressed the need for continued research into the many aspects of kwashiorkor, including the social and cultural factors contributing to the causation of the disease (FAO/WHO: Joint Expert Committee on Nutrition, 1953).

It also suggested that some regional meetings should be convened from time to time to review progress and recommend lines of research. With the generous financial assistance of the Josiah Macy Jr. Foundation it was possible to hold such a meeting in 1953 in Jamaica (FAO/WHO/Josiah Macy Jr. Foundation, 1955). In this first meeting workers from different parts of the world described the work in which they were engaged, and much time was given to clarifying points and putting up new ideas for discussion and challenge. No formal agenda was used and interruption and free discussion were encouraged. This technique has been developed over the past ro years by the Macy Foundation in the belief that it is more effective in promoting the useful exchange of ideas than the traditional formal procedure, and experience in Jamaica confirmed this view. The value of the meeting has been amply demonstrated, in that it has influenced the lines along which research has proceeded in different centres. WHO has followed up this initial exchange and pooling of experience by making provision for the exchange of workers. The Director of the Medical Research Council Group for Research in Infantile Malnutrition, Kampala, Uganda, has visited the Institute of Nutrition of Central America and Panama in Guatemala, and two workers in that Institute have studied the problem of kwashiorkor in Uganda. The Deputy Director of the Nutrition Laboratories of the Indian Council for Medical Research has also spent some time at Kampala.

The international organizations are primarily concerned with the prevention of disease, and it is this aspect of kwashiorkor which has been our main pre-occupation in all these activities. Conference promoting in itself does not produce immediate material advances. However, as a result of these efforts, a number of well-informed people in different parts of the world are now working in co-operation along agreed lines, and this we regard as an important achievement.

Other efforts towards prevention of kwashiorkor have been determined by the two main conditions, mentioned by Aykroyd (1956), under which protein malnutrition occurs-namely complete or partial lack of protein-rich foods in the environment, or a failure on the part of the people to make use of the foods available.

When considering the first-the lack of suitable protein foods-in relation to the young child, breast feeding obviously has an important part to play. During the first few months of life it is usually sufficient for the adequate nourishment of the child, but what happens after this period is decisive in this disease. Where suitable protein is not available prolongation of breast feeding may be of the utmost importance even when the secretion of milk is small.

\section{Vegetable-protein substitutes for cow's milk}

Cow's milk remains the best food for the transition from breast milk to the adult 
diet but the production of milk throughout the world is not likely, in the foreseeable future, to meet the needs of the world's children. Milk production is expensive in terms of land, and cheaper sources of protein must therefore be found. It seemed natural to try to develop suitable protein from vegetable sources.

Some of the pioneer work in this field was done by a British Medical Research Council team in Germany, and the results were reported to this Society (Dean, I95I) and later published in full (Dean, 1953). These preliminary attempts to replace milk in the feeding of infants by a mixture of cereals and soya, were so encouraging that the M.R.C. decided to continue this work, and considered that it could best be done in Africa where protein malnutrition was to be found. The protein of soya having been used successfully, it seemed reasonable to hope that prophylaxis of kwashiorkor by plant proteins might be possible. The best practical approach has proved to be the treatment of the mild case of the disease with plant proteins. This group in Africa has so far carried out the laboratory and small-scale investigations of various food materials that might be used for supplying additional protein to children's diets. It has already been shown that some of the local beans, groundnuts and cottonseed meal, as well as soya, are of value in this respect.

At the Nutrition Laboratories in Coonoor, Bengal, gram (Cicer arietinum) in combination with other foodstuffs, has been used with some success in treating kwashiorkor. The results up to the present time have not been entirely satisfactory and the investigations are now directed towards other supplements to the Bengal gram which would make it a satisfactory basic foodstuff for preventing kwashiorkor.

In the Institute of Nutrition of Central America and Panama in Guatemala, work is also proceeding on the development of food mixtures, derived from plant sources available in that region, for use in the treatment of protein malnutrition. These will provide a basis for a cheaper acceptable nutritious food for infants generally.

These centres are, we hope, foci from which the techniques of investigation and development of foods for young children will spread. As each centre develops its programme of work, we will try to stimulate interest and activity in other centres in the region and concentrate on an exchange of workers at a regional level rather than the present wider geographical basis. The problems differ in different countries and among different peoples in the same country, and it is likely that a good deal of work will be required at the local level. FAO and UNICEF are also interested in encouraging this work. FAO is concerned with food production and food technology and UNICEF can give valuable assistance towards the cost of pilot plants for producing suitable protein-rich foods of plant origin.

Dr Aykroyd and I have just returned from a meeting in the USA convened by FAO and WHO and the Josiah Macy Jr. Foundation, at which various aspects of the development of protein foods were considered. Leading workers in child nutrition from the United States and Europe and from India, Africa and Latin America discussed the steps and investigations necessary before any product can be introduced into general use. They also considered the resources-the money and technical skills - that may be available for assisting the development of such products.

The activity going on in these centres and in others in a few countries is an 
extremely important development in the field of public health and will, I feel certain, receive more and more attention in the future.

\section{Education in use of locally available foods}

The second main approach to the prevention and alleviation of protein and other forms of malnutrition-education of the people in the use of the available, or newly introduced foods-also claims our attention.

Aykroyd (1956) has referred to the joint FAO/WHO courses in nutrition and to the seminar to be held in Manila towards the end of this year. As far as WHO is concerned this seminar is a joint activity of the Health Education of the Public and the Nutrition Sections, for two reasons - firstly, the requesting governments have stressed that they wish the emphasis to be on the educational approaches rather than the nutritional content, and secondly, in WHO, nutrition education is regarded as an inseparable part of health education in general. The health educator is viewed, not so much as a teacher of any one aspect of health, but rather as a social catalyst, trained in the basic sciences and the principles of education and community action. Such a person, it is felt, can act as a stimulating and co-ordinating agent in a community, helping people to a better understanding of their difficulties, and to overcome them by making use of the various resources, human and material, within their reach. This concept of the functions of a health educator is particularly useful in the underdeveloped countries where the problem of malnutrition is so closely linked with other aspects of public health, such as sanitation, communicable disease, and with agriculture and the whole way of life of the people.

When we inquire into the reason for the all too frequent disregard of local foods we soon find ourselves in the baffling maze of tradition, taboo and magic and of the whole system of belief of the people about health and the causes of disease. In the past most workers have tried, by repeated blows of didactic teaching, to hammer their way through this maze, and break down the resistances to unaccustomed foods and eating practices-with very little success.

More recently, we have come to realize that beliefs about food are part of the whole fabric of the life of a people and cannot be changed in isolation, and that the feeding customs which have become established through centuries of trial and error have developed as part of the people's reaction to the total environment in which they have learned to survive.

Sometimes an isolated change will produce unforeseen and undesired results. It is thought that, in some places, the present-day incidence of kwashiorkor has been encouraged by the breakdown, under western influence, of the old habit of separation of the husband and wife after the birth of a child. This separation, enforced by tradition, afforded the child a prolonged period at the breast, and ensured its greater maturity when the time of weaning arrived-and therefore a greater chance of survival.

In order to avoid such untoward results in the future, we have turned to the anthropologist whose knowledge of the social structure and habitual practices of a 
people can help us to predict, to some extent, the effects of changes in these practices. He can also help us 'not to judge whether prevailing beliefs and practices are scientifically valid or bizarre' but to 'determine in what ways they influence acceptance of action measures' (Wellin, 1955).

The advances in our knowledge of how people learn, and what induces any of us to change our long-established habits, have altered our approach to the problem of nutrition education. We now realize that didactic teaching is largely ineffective except where there is a strong desire to learn, and that people will change their ways of doing things only if they recognize the advocated change as a means to an end that they themselves desire.

We have therefore arranged that at Manila there will be well-known workers from these disciplines-anthropology and community education-who will spend the 3 weeks of the seminar exchanging knowledge and experience with administrators and potential nutrition educators from different countries in that region.

Some useful contributions to nutrition education have already been made by anthropologists working with WHO projects in different parts of the world, including a report on child feeding and food ideology in Peru (Wellin, 1953) and another on the medical beliefs and practices in a Guatemalan Indian town (Adams, I952).

Those of us already familiar with the beliefs and practices of some Asian peoples about food and health are impressed with the similarities rather than the differences between East and West in this respect.

Recently, following the Expert Committee's recommendation, a social anthropologist has spent 6 months in Indonesia studying the social and cultural factors associated with protein and other forms of malnutrition in children. Already considerable clinical investigation of malnutrition in children in that country has been carried out by a WHO consultant and it is hoped that information on such things as (I) attitudes towards infant mortality, (2) the relationships between family instability and sickness, especially malnutrition, (3) the influence on nutritional status of adoption and of the different treatment of male and female children, (4) class structure and social mobility in their relation to food and patterns of consumption, will add to our understanding of the causative influences. In view of the forthcoming seminar in Manila, attention was also given to the influence of urbanization on community life, considered from the point of view of the emergence of leadership and the isolation of individuals and households, and also the channels for the propagation of health instruction and the relative effectiveness of different media.

It has always been recognized that nutrition education must cover many aspects of life, but its scope has been widened still further by some recent work by the Medical Research Council's Group for Research in Infantile Malnutrition (Geber \& Dean, 1955). A study, sponsored by the Mental Health Section of WHO, of the psychological changes in kwashiorkor has suggested that a separation of the mother and child - either by the child being sent away to stay with a relative or by the sudden weaning and subsequent banishment of the child from its customary contact with the mother-may be an important factor in the onset of the disease. It was found that the 'anorexia of despair' so often associated with kwashiorkor could be overcome 
without recourse to forced feeding, if the child was mothered by the hospital nursing staff. The implications of such findings are far reaching.

In this account $I$ have mentioned only those WHO activities that $I$ thought would be of most interest. Other important fields of work such as our attempts to control pellagra, the proposed study of atherosclerosis and the investigation of the public-health significance of the nutritional anaemias are dealt with in the Joint Expert Committee Report (FAO/WHO: Joint Expert Committee on Nutrition, 1955). The combined efforts of FAO, WHO and UNICEF will be described more fully by other speakers.

Whatever stage of economic development a country may have reached, there seems to be a great deal of work to be done in the public-health aspects of nutritional disease, in which the international agencies will, I hope, be able to play a constructive part.

\section{REFERENCES}

Aykroyd, W. R. (1956). Proc. Nutr. Soc. 15, 4.

Adams, R. N. (1952). An Analysis of Medical Beliefs and Practices in a Guatemalan Indian Town. Mimeo.

Autret, M. \& Behar, M. (1954). Bull. World Hlth Org. 11, 89 I.

Brock, J. F. \& Autret, M. (1952). World Hlth Org. Monogr. Ser, no. 8.

Commission for Technical Co-operation in Africa, South of the Sahara (CCTA) (1954). Report of the Second Inter-African (CCTA) Conference on Nutrition. London: H.M. Stationery Office.

Dean, R. F. A. (195I). Brit. Y. Nutr. 5, 269.

Dean, R. F. A. (1953). Spec. Rep. Ser. med. Res. Coun., Lond., no. 279.

FAO/WHO: Joint Expert Committee on Nutrition (1950). WHO tech. Rep. Ser. no. I6.

FAO/WHO: Joint Expert Committee on Nutrition (1953). WHO tech. Rep. Ser. no. 72.

FAO/WHO: Joint Expert Committee on Nutrition (1955). WHO tech. Rep. Ser. no. 97.

FAO/WHO/Josiah Macy Jr. Foundation (1955). Protein Malnutrition. Proceedings of a Conference in Famaica (1953). [J. C. Waterlow, editor.] Cambridge: University Press.

Geber, M. \& Dean, R. F. A. (1955). Bull. World Hlth Org. 12, 47 I.

Holman, J. C. M. (1953). Bull. World Hlth Org. 9, 231.

Kelly, F. C. (1953). Bull. World Hlth Org. 9, 217.

McCarrison, R. (1917). The Thyroid Gland in Health and Disease. London: Ballière, Tindall \& Cox.

Medical Research Council: Goitre Subcommittee (1944). Lancet, 246, 107.

Murray, M. M. (1953). Bull. World Hlth Org. 9, 211.

Murray, M. M. \& Pochin, E. E. (195I). F. Physiol. 114, 6P.

Ramalingaswami, V. (1953). Bull. World Hlth Org. 9, 275.

Scrimshaw, N. S., Cabezas, A., Castillo, F. \& Méndez, J. (1953). Lancet, 265, 166.

Waterlow, J. C. \& Vergara, A. (I955). To be published.

Wellin, E. (1953). Child Feeding and Food Ideology in a Peruvian Village. Mimeo.

Wellin, E. (1955). Nutr. Rev. 13, 129. 